\title{
Reakcja administracji Jimmy'ego Cartera na komunistyczny przewrót i wkroczenie wojsk sowieckich do Afganistanu
}

\section{Wprowadzenie}

Przedmiotem analizy jest reakcja administracji prezydenta Jimmy'ego Cartera na Rewolucję Saur z kwietnia 1978 r. i początkowy etap inwazji na Afganistan rozpoczętej w grudniu 1979 r. Artykuł prezentuje wewnętrzne tarcia między członkami amerykańskiej administracji, którzy mieli największy wpływ na kształtowanie w tym okresie polityki zagranicznej Stanów Zjednoczonych wobec Afganistanu i Związku Sowieckiego. Przeanalizowane są decyzje o charakterze politycznym, gospodarczym i militarnym podjęte przez rząd amerykański wobec tych krajów oraz konsekwencje zastosowanych wobec nich działań.

Zdystansowana polityka Stanów Zjednoczonych wobec Afganistanu po drugiej wojnie światowej umożliwiła Związkowi Sowieckiemu stopniowe umacnianie wpływów w tym kraju. W pierwszych latach powojennych to Stany Zjednoczone stały się głównym partnerem handlowym Afganistanu, odbierając większość jego podstawowych towarów eksportowych, tj. skór karakułowych, owoców i orzechów (które łącznie stanowiły 74 proc. wartości eksportu $)^{1}$, co trwało do końca lat pięćdziesiątych XX w. ${ }^{2}$ Uczestniczyły również w modernizacji kraju, angażując się m.in. w budowę systemów irygacyjnych, elektrowni wodnych i dróg w dolinach rzek Helmand i Arghandab ${ }^{3}$. Amerykanie udzielali Afganistanowi pożyczek na wiele innych inwestycji w zakresie infrastruktury transportowej, rozwoju przemysłu, systemu szkolnictwa itd., jednak pomoc ta daleko odbiegała od oczekiwań kolejnych rządów afgańskich, które najchętniej wyobrażały sobie Stany Zjednoczone w roli głównego partnera pomocowego. Sytuację tę wykorzystał Związek Sowiecki. Pragnąc wciągnąć Afganistan w sferę swoich wpływów, w latach 1956-1978 przekazał Afganistanowi pomoc gospodarczą o wartości 1,26 mld dolarów i pomoc militarną o wartości 1,25 mld dolarów. W tym okresie Stany

${ }^{1}$ J. Modrzejewska-Leśniewska, Afganistan, Warszawa 2009, s. 194.

${ }^{2}$ M. Jabeen, M. S. Mazhar, N. S. Goraya, US Afghan Relations: A Historical Perspective of Events of 9/11, „A Research Journal of South Asian Studies” 2010, t. XXV, s. 145, 146, za: M. K. Ma'aroof, Afghanistan and Super Powers, New Delhi 1990, s. 140.

${ }^{3}$ K. Harvey, Afghanistan, The United States, and the Legacy of Afghanistan's Civil War, http://www. stanford.edu/class/e297a/Afghanistan,\%20the\%20United\%20States.htm, [dostęp: 4 V 2014]. 
Zjednoczone przekazały Afganistanowi pomoc o łącznej wartości zaledwie 533 mln dolarów, z czego większość w latach pięćdziesiątych XX w., ponieważ później Amerykanie tracili zainteresowanie tym krajem ${ }^{4}$. Zawiodły kalkulacje Amerykanów z lat siedemdziesiątych XX w., polegające na tym, że istotne wsparcie pomocowe ze strony sojuszników amerykańskich z regionu, tj. Iranu i Kuwejtu, utrzyma Afganistan poza strefą wpływów sowieckich ${ }^{5}$.

Podstawowym problemem we wzajemnych relacjach była jednak niechęć Amerykanów do udzielenia Afgańczykom pomocy militarnej. Strona afgańska wielokrotnie zwracała się do USA o pomoc w modernizacji i szkoleniu armii. Amerykanie konsekwentnie odmawiali, jednocześnie istotnie wspierając w tym zakresie sąsiadujący z Afganistanem Pakistan. Postawiło to Afganistan w trudnej sytuacji politycznej, ponieważ znajdował się on w poważnym sporze granicznym z sąsiadem w sprawie terytoriów zamieszkanych przez Pasztunów ${ }^{6}$. W związku z tym już w latach pięćdziesiątych XX w. premier Mohammed Daud Chan (1953-1963) zmuszony był do zakupu w ZSRS znacznej ilości uzbrojenia, w tym czołgów T-34 i myśliwców MiG-17 $7^{7}$ Z kolei w latach siedemdziesiątych XX w. do kraju zaczęły napływać liczne grupy sowieckich instruktorów i doradców wojskowych ${ }^{8}$. W tym czasie Stany Zjednoczone, licząc na trwałe osłabienie napięć w stosunkach z ZSRS w ramach détente, nie chciały prowokować potężnego rywala nadmiernym angażowaniem się w sprawy afgańskie?

Prowadzona przez kolejne powojenne rządy afgańskie polityka bi-tarifi, polegająca na zachowaniu w stosunkach politycznych i gospodarczych równowagi między Wschodem i Zachodem, nie powiodła się, głównie ze względu na niechęć do poważniejszego zaangażowania się Stanów Zjednoczonych w pomoc Afganistanowi ${ }^{10}$. Amerykanie nie potrafili lub nie chcieli trafnie odczytywać wyraźnych sygnałów ze strony zainteresowanego zacieśnianiem współpracy Afganistanu. Nie byli także skorzy wesprzeć demokratycznych reform zainicjowanych przez króla Mohammeda Zahir Szaha (1933-1973), mimo że uważali się za adwokata demokracji i wolności na świecie ${ }^{11}$.

\section{Stany Zjednoczone wobec przejęcia władzy w Afganistanie przez komunistów}

Mimo okresowego ciążenia ku ZSRS w schyłkowej fazie sprawowania władzy przez prezydenta Mohammeda Daud Chana (1973-1978) coraz wyraźniej rysowała się proamerykańska orientacja afgańskiego rządu ${ }^{12}$. W 1977 r. prezydent Daud zdecydował się nawet uwięzić część kierownictwa obu stronnictw Ludowo-Demokratycznej Partii Afganistanu (LDPA), tj. Chalku i Parczamu. Było to zgodne z interesem amerykańskim, ponieważ partia ta od samego początku działalności szerzyła idee marksizmu-leninizmu i głosiła konieczność walki z imperializmem ${ }^{13}$. Represje wobec komunistycznych przywódców okazały się poważ-

\footnotetext{
${ }^{4}$ A. Rashid, Talibowie. Wojujacy islam, ropa naftowa i fundamentalizm w środkowej Azji, tt. D. Chylińska, A. Lipszyc, J. Piątkowska, Kraków 2002, s. 38.

${ }^{5}$ R. Anwar, The Tragedy of Afghanistan: A First hand Account, London 1988, s. 34, 35.

${ }^{6}$ J. Petrus, W Afganistanie, kraju buzkaszi, Warszawa 1974, s. 84-86.

7 J. Polit, Środkowowschodnie reformy i przewroty, w: Historia polityczna świata XX wieku. 19452000, red. M. Bankowicz, Kraków 2004, s. 285.

${ }^{8}$ R. Sikorski, Prochy świętych. Afganistan czas wojny, Warszawa 2007, s. 311.

9 K. W. Olson, An Outline of American History, Washington 1978, s. 176.

${ }^{10}$ M. Gawęcki, Wieś środkowego i pótnocnego Afganistanu, Wrocław 1983, s. 50, 51.

${ }^{11}$ M. Jabeen, M. S. Mazhar, N. S. Goraya, op. cit., s. 152.

${ }^{12}$ M. Gawęcki, op. cit., s. 50.

${ }^{13}$ V. Mitrokhin, The KGB in Afghanistan, July 2002-updated July 2009, s. 22, 23, http://www.wilsoncenter.org/sites/default/files/WP40-english.pdf.
} 
nym błędem, ponieważ dysponowali oni dużymi wpływami w armii ${ }^{14} .27$ IV 1978 r. ludzie Hafizullaha Amina ze stronnictwa Chalk dopuścili się mordu na prezydencie Mohammedzie Daud Chanie, jego rodzinie i członkach rządu ${ }^{15}$. Przywódca Chalku Mohammed Nur Taraki stanął na czele Rady Rewolucyjnej Demokratycznej Republiki Afganistanu, obejmując jednocześnie funkcję prezydenta (30 IV 1978-14 IX 1979) i premiera kraju (1 V 1978-27 III $1979)^{16}$. Babrak Karmal i inni przywódcy konkurencyjnego skrzydła LDPA — Parczamu, po krótkim, przejściowym okresie partycypacji we władzy, musieli udać się w roli ambasadorów na honorową emigrację ${ }^{17}$. Wraz z Rewolucją Saur LDPA (nawa Saur pochodzi od miesiąca kwietnia) zmienił się stosunek Stanów Zjednoczonych do Afganistanu z ograniczonej współpracy do niechęci i stopniowego wycofywania ${ }^{18}$.

Po stronie Stanów Zjednoczonych widoczne było zaskoczenie rozwojem sytuacji, a raport Departamentu Stanu z 26 III 1978 r. odkrywa zaniedbania amerykańskiej dyplomacji kierowanej przez sekretarza stanu Cyrusa Vance'a (1977-1980). Miesiąc przed zamachem stanu przedstawiał on sytuację w Afganistanie jako stabilną, pozycję prezydenta uważał za niezagrożoną, natomiast opór opozycji za nieznaczny ${ }^{19}$. Po przewrocie waszyngtońscy urzędnicy zaczęli analizować, czy Moskwa była za niego współodpowiedzialna. Mimo wielu wątpliwości i oczywistych związków LDPA z KPZR (Komunistyczna Partia Związku Radzieckiego) sekretarz stanu USA poinformował, że nie znaleziono dowodów potwierdzających udział Związku Sowieckiego w zamachu stanu, co potwierdzają współczesne badania $^{20}$. Jednocześnie przekonał on prezydenta Jimmy'ego Cartera (1977-1981), aby utrzymać współpracę z nowym rządem afgańskim i obserwować dalszy rozwój wydarzeńn ${ }^{21}$.

Rząd Mohammeda Tarakiego ogłosił, że będzie niekomunistyczny, a w polityce zagranicznej zapowiedział kontynuowanie polityki niezaangażowania. Amerykańska dyplomacja oceniła, że w praktyce rząd ten faktycznie powinien być bardziej nacjonalistyczny niż komunistyczny. Było to sprzeczne z danymi Centralnej Agencji Wywiadowczej (Central Intelligence Agency - CIA) kierowanej przez Stansfielda Turnera (1977-1981), która dysponowała biografiami poszczególnych członków nowego rządu afgańskiego, jednoznacznie potwierdzającymi ich komunistyczne przekonania ${ }^{22}$. Aby nie eskalować napięcia, Departament Stanu poinformował jednak o chęci kontynuowania zaangażowania w kraju, co zostało przyjęte przez afgański reżim. Sekretarz stanu Cyrus Vance wysłał do Kabulu podsekretarza stanu ds. politycznych Davida Newsoma (1978-1981) w celu omówienia kwestii kontynuacji amerykańskich programów edukacyjnych i kulturalnych oraz wsparcia gospodarczego ${ }^{23}$. Równolegle poinstruował jednak ambasadora USA w Kabulu Theodora L. Eliota Jr. (19731978), że jedną z prawdopodobnych opcji działania może być stopniowe wygaszanie aktyw-

\footnotetext{
${ }^{14}$ Ł. Jureńczyk, Wojna z talibami i Al-Kaida. Afganistan w latach 1994-2012, Toruń 2013, s. 37.

15 J. C. Griffiths, Afghanistan: Key to a Continent, London 1981, s. 178.

16 J. Modrzejewska-Leśniewska, Afganistan, s. 305.

${ }_{17}$ P. Calvocoressi, Polityka międzynarodowa po 1945 roku, tł. W. Bolimowska-Garwacka, Warszawa 1998, s. 546.

${ }_{18}$ J. Modrzejewska-Leśniewska, Polityka Stanów Zjednoczonych i Związku Radzieckiego wobec Afganistanu w latach 1947-1979, Warszawa 2009, s. 379.

${ }^{19}$ M. Jabeen, M. S. Mazhar, N. S. Goraya, op. cit., s. 154, za: T. T. Hammond, Red Flag Over Afghanistan: The Communist Coup, the Soviet Invasion and the Consequences, Colo 1984, s. 63.

${ }^{20}$ V. Mitrokhin, op. cit., s. 2.

${ }^{21}$ K. Tadman, An American Provocation: U.S. Foreign Policy during the Soviet-Afghanistan War, „Western Illinois Historical Review” 2013, t. V, Spring, s. 38, 39.

${ }^{22}$ S. G. Jones, In the Graveyard of Empires. America's War in Afghanistan, New York 2010, s. 13.

${ }^{23}$ K. Tadman, op. cit., s. 38.
} 
ności w Afganistanie, ponieważ Stany Zjednoczone nie mogą wspierać władz zależnych od Moskwy ${ }^{24}$. Jednocześnie amerykańskie prawo zakazywało dostarczania pomocy partiom komunistycznym ${ }^{25}$. Wyważona reakcja amerykańskiej dyplomacji wpisywała się w ogólną postawę społeczności międzynarodowej. Ogłoszenie przez Moskwę włączenia Afganistanu do bloku socjalistycznego ,nie wywołało międzynarodowego sprzeciwu, tak więc nieformalnie zostało zaakceptowane przez społeczność międzynarodową ${ }^{26}$. Warto zauważyć, że prezydent Carter nie mógł być pewien wsparcia europejskich sojuszników, gdyby zaryzykował bardziej zdecydowane działania, co potwierdzała kwestia mieszania się ZSRS w sprawy Angoli w 1977 r. oraz Somalii i Etiopii w 1978 r. Znamienne było, że część zachodnioeuropejskich przywódców zarzucała Amerykanom bezczynność, a gdy ci decydowali się na reakcję, narzekano na konsekwencje ich interwencji ${ }^{27}$.

Doradca ds. bezpieczeństwa narodowego Zbigniew Brzeziński (1977-1981) ostrzegał prezydenta Jimmy'ego Cartera, że komunistyczny przewrót w Afganistanie jest poważnym zagrożeniem dla amerykańskich interesów w regionie. Uważał, że Związek Sowiecki może za pośrednictwem Afganistanu rozciągnąć swoje wpływy na Pakistan i Iran, a może nawet całą Azję Południową. Prezydent Carter próbował jednak na początku kadencji porzucić „mit” o konieczności rywalizacji i konfrontacji supermocarstw. Wynikało to między innymi ze wstydu odczuwanego za nadużycia poprzednich administracji w postaci potajemnych interwencji politycznych, wspierania prawicowych dyktatur i szczególnie wojny $\mathrm{w}$ Wietnamie ${ }^{28}$. Było to o tyle istotne, że to właśnie prezydent inspiruje w amerykańskim społeczeństwie uczucia lojalności i patriotyzmu, szczególnie w okresie kryzysu ${ }^{29}$. Carter chciał w polityce zagranicznej stopniowo odchodzić od koncepcji równowagi sił w stosunkach Wschód-Zachód na rzecz rozwijania pokojowej polityki ,światowego ładu”. Jednocześnie pragnął znacznie więcej uwagi poświęcić rozwijaniu pozytywnych relacji na linii PółnocPołudnie, czyli między krajami rozwiniętymi a rozwijającymi się ${ }^{30}$. Kładł też duży nacisk na kwestię promowania praw człowieka $\mathrm{w}$ innych krajach ${ }^{31}$. W związku $\mathrm{z}$ tym dystansował się w tym czasie od rad Zbigniewa Brzezińskiego, aby zerwać stosunki z nowym rządem afgańskim i zaostrzyć kurs wobec ZSRS. Tym samym oparł się na propozycji sekretarza stanu Cyrusa Vance'a, polegającej na wyczekiwaniu w nadziei, że premier Mohammed Taraki nie pozwoli na uzależnienie kraju od Moskwy. Warto podkreślić, że ostatnie zdanie należało tu do prezydenta Cartera, ponieważ za kwestie bezpieczeństwa i podstawowych kierunków polityki zagranicznej odpowiada w USA głowa państwa ${ }^{32}$.

W celu realizacji umiarkowanej strategii działania wobec Afganistanu prezydent Carter mianował na ambasadora USA w Kabulu Adolpha Dubsa (1978-1979). Nowy ambasador aktywnie zabiegał o dobre relacje z rządem Tarakiego, mając nadzieję, że amerykańskie wsparcie powstrzyma umacnianie wpływów sowieckich w tym kraju ${ }^{33}$. Adolph Dubs został

${ }^{24}$ M. Jabeen, M. S. Mazhar, N. S. Goraya, op. cit., s. 155.

25 S. G. Jones, op. cit., s. 13.

${ }^{26}$ N. P. Newell, R. S. Newell, The Struggle for Afghanistan, Ithaca-London 1982, s. 195, 196.

27 A. Grosser, The Western Alliance. European-American Relations Since 1945, New York 1980, s. 312.

28 J. Spanier, Polityka zagraniczna Stanów Zjednoczonych po II wojnie światowej, Toruń 1998, s. 18.

${ }^{29}$ R. A. Watson, Promise and Performance of American Democracy with an In-depth Analysis of the 1980 Presidential Contest, New York 1981, s. 344.

30 J. Spanier, op.cit., s. 18.

31 D. Mauk, J. Oakland, American Civilization. An Introduction, London-New York 2003, s. 166.

32 G. C. Mackenzie, American Government. Politics and Public Policy, New York 1986, s. $182,183$.

${ }_{33}$ Milestones:1977-1980. The Soviet Invasion of Afghanistan and the U.S. Response, 1978-1980, 31 X 2013, https://history.state.gov/milestones/1977-1980/soviet-invasion-afghanistan [dostęp: 18 IV 2014$].$ 
jednak zastrzelony 14 II 1979 r. podczas akcji odbicia z rąk porywaczy z szyickiej grupy dysydenckiej Setem-i Melli. Prawdopodobnie zginął od kuli policjanta, a sama akcja odbicia została przeprowadzona wbrew stanowisku Amerykanów, którzy chcieli porozumieć się z porywaczami, gotowymi przystać na takie rozwiązanie sprawy ${ }^{34}$. Rząd Tarakiego odmówił stronie amerykańskiej prawa przeprowadzenia śledztwa w sprawie śmierci ambasadora ${ }^{35}$. Rząd USA zgłosił oficjalny protest na działania afgańskiej policji i jej sowieckich doradców. Wątek sowiecki odegrał tu istotną rolę, ponieważ w felernej akcji brało udział dwóch Rosjan, z których jeden rozstawiał afgańskich snajperów i kierował ogniem ${ }^{36}$.

Wraz ze śmiercią ambasadora Dubsa zakończyła się amerykańska pomoc gospodarcza dla Afganistanu ${ }^{37}$. Decyzję w tej sprawie podpisał prezydent Carter 14 VIII 1979 r. Zaprzestanie wsparcia miało trwać do czasu oficjalnych przeprosin za incydent ze strony afgańskich władz. Wcześniej, bo 23 lipca, Amerykanie wycofali z kraju większość dyplomatów, pracowników zatrudnionych przy programach pomocowych i urzędników, co argumentowali względami bezpieczeństwa ${ }^{38}$. Co ciekawe, komunistyczna rewolucja Saur nie sprowokowała Stanów Zjednoczonych do podjęcia zdecydowanych działań. Dopiero zamordowanie ambasadora Dubsa zaktywizowało rząd amerykański. Ta wstrzemięźliwość i niezdecydowanie Waszyngtonu wyraźnie dodały Sowietom śmiałości w dalszych poczynaniach wobec Afganistanu $^{39}$.

Szczęśliwie dla Waszyngtonu komunistyczny rząd okazał się skrajnie niepopularny wśród większości Afgańczyków ${ }^{40}$. Próby narzucania obcej ideologii, podważającej prymat religii i dominującą pozycję mężczyzny w społeczeństwie, doprowadziły do pojawiania się ognisk powstańczych w różnych częściach kraju. Komunistyczna armia afgańska regularnie prowadziła pacyfikację przyczółków rebeliantów, a stopniowo w działania te wciągani byli Sowieci. W marcu 1979 r. na prośbę Mohammeda Tarakiego ${ }^{41}$ strona sowiecka wsparła pacyfikację miasta Herat w zachodnim Afganistanie, w której wyniku zginęło 3-5 tys. osób ${ }^{42}$. Stany Zjednoczone również zmagały się w tym czasie $\mathrm{z}$ poważnym problemem w regionie. Zaprzyjaźniony z USA wieloletni szach Iranu Mohammed Reza Pahlawi (1941-1979) musiał 16 I 1979 r. uciekać z kraju w wyniku rewolucji islamistycznej inspirowanej przez zwolenników ajatollaha Ruhollaha Chomejniego. Z kolei 4 listopada grupa teherańskich radykałów zaatakowała i zajęła amerykańską ambasadę, biorąc do niewoli pięćdziesięciu dwóch zakładników ${ }^{43}$. Nie tylko znacząco osłabiło to amerykańską pozycję w regionie, ale również odcięło Afganistan od wsparcia gospodarczego ze strony Iranu, które w zainicjowanym w 1976 r. siedmioletnim planie gospodarczym miało wy-

\footnotetext{
${ }^{34}$ S. G. Jones, op. cit., s. 15.

35 J. Meher, America's Afghanistan War: The Success that Failed, Delhi 2004, s. 64.

${ }^{36}$ J. Modrzejewska-Leśniewska, Afganistan, s. 321, 322.

${ }^{37}$ M. Jabeen, M. S. Mazhar, N. S. Goraya, op. cit., s. 155, za: K. P. Misra, Afghanistan in Crisis, New Delhi 1981, s. 54.

${ }^{38}$ J. Modrzejewska-Leśniewska, Afganistan, s. 323.

${ }^{39}$ K. Tadman, op. cit., s. 34.

${ }^{40} \mathrm{~K}$. Harvey, op. cit.

${ }^{41}$ Transcript of Telephone Conversation Between Soviet Premier Alexei Kosygin and Afghan Prime Minister Nur Mohammed Taraki, 17 III 1979, http://digitalarchive.wilsoncenter.org/document/113262 [dostęp: 23 X 2014].

${ }^{42}$ A. J. Joes, Resisting Rebellion. The History and Politics of Counterinsurgency, Lexington 2006, s. 68; J. Polit, Radziecka interwencja w Afganistanie, w: Historia polityczna świata..., s. 545.

${ }^{43}$ R. Piski, Teheran świętuje 29. rocznice zajęcia ambasady USA, 4 XI 2008, http://www.psz.pl/ tekst-14587/Teheran-swietuje-29-rocznice-zajecia-ambasady-USA [dostęp: 23 IV 2014].
} 
nieść 1,14 mld dol., czyli najwięcej spośród wszystkich państw, w tym prawie dwukrotnie więcej niż od ZSRS ${ }^{44}$.

W pierwszych miesiącach 1979 r. Zbigniewowi Brzezińskiemu udało się przeprowadzić przez Specjalną Radę Koordynacyjną (Special Coordination Council - SCC) wchodzącą w skład Rady Bezpieczeństwa Narodowego (National Security Council — NSC) decyzję o konieczności bycia „,bardziej przychylnymi wobec Afgańczyków zdeterminowanych do utrzymania niepodległości kraju"45. Dane CIA i Sekretariatu Stanu ujawniają, że na podstawie decyzji SCC rozpoczęły się w tym czasie tajne spotkania z przedstawicielami afgańskich bojowników zwanych mudżahedinami ${ }^{46}$. Latem tego samego roku w Afganistanie zaczęli pojawiać się oficerowie CIA w celu rozpoznania sytuacji i przygotowania gruntu pod ewentualne szczersze wsparcie rebeliantów ${ }^{47}$. 3 VII 1979 r. prezydent Carter podpisał pierwszą decyzję o wsparciu mudżahedinów ${ }^{48}$. Dotyczyła ona pomocy dla powstańczej propagandy, ułatwienia Afgańczykom dostępu do radia przez wykorzystanie instalacji z różnych krajów oraz dostarczenia pieniędzy i pozawojskowego zaopatrzenia dla grup opozycyjnych ${ }^{49}$. Pomoc w tym zakresie zaczęła napływać do Afganistanu od sierpnia 1979 r. ${ }^{50}$

W tym okresie w Afganistanie pojawiło się ok. 4 tys. sowieckich doradców, a kraj otrzymał także pierwsze partie sowieckich czołgów T-62, helikopterów Mi-24 i samolotów MiG-23. Prezydent Mohammed Taraki bezskutecznie zabiegał w Moskwie o lądową interwencję zbrojną w celu zdławienia buntu. W tym celu wraz z Hafizullahem Aminem odbyli podróż do Moskwy, gdzie podpisali traktat o przyjaźni, który zawierał klauzulę umożliwiającą Związkowi Sowieckiemu bezpośrednie wsparcie militarne w sytuacji, gdyby islamistyczna rewolucja zagroziła reżimowi. W sierpniu 1979 r. do Kabulu przybyła wysokiej rangi sowiecka delegacja wojskowa. Amerykańska dyplomacja brała pod uwagę ewentualność, że wizyta może być przygotowaniem do rozstrzygnięcia militarnego, jednak nadal uznawała tę ewentualność za mało prawdopodobną ${ }^{51}$.

W LDPA trwał wówczas konflikt między prezydentem Mohammedem Tarakim a premierem Hafizullahem Aminem (27 III 1979-27 XII 1979). Ich partyjni stronnicy rozsiewali plotki o agenturalnej działalności na rzecz USA przywódcy obozu przeciwników ${ }^{52}$. Premier Amin trafnie odczytał wizytę delegacji sowieckiej jako próbę wzmocnienia pozycji Tarakiego kosztem jego samego jako nieprzewidywalnego i szczególnie destabilizującego sytuację w kraju. Jeszcze 13 IX 1979 r. Politbiuro KPZR doradzało Tarakiemu, aby porozumiał się z Aminem lub go aresztowat ${ }^{53}$. Tego dnia premier Amin oskarżył trzech lojalnych wobec prezydenta

\footnotetext{
${ }^{44}$ N. P. Newell, R. S. Newell, op. cit., s. 51, za: L. Duprée, Afghanistan 1977: Does Trade Plus Aid Guarantee Development? American Universities Field Staff Reports, „South Asia Series” 1977, t. XXI, nr 3, s. 10.

${ }^{45}$ Z. Brzeziński, Power and Principle. Memoirs of the National Security Adviser. 1977-1981, Washington 1983 , s. 427.

${ }^{46}$ K. Harvey, op. cit., za: Digital National Security Archive.

${ }^{47}$ K. Tadman, op. cit., s. 42.

${ }^{48}$ M. C., The CIA's Intervention in Afghanistan. Interview with Zbigniew Brzezinski, http://www.global research.ca/articles/BRZ110A.html [dostęp: 2 X 2014].

${ }^{49}$ R. M. Gates, From the Shadows. The Ultimate Insider's Story of Five Presidents and How They Won the Cold War, New York-London 2006, s. 145, 146.

${ }^{50}$ J. Modrzejewska-Leśniewska, Afganistan, s. 323.

${ }^{51}$ Milestones: 1977-1980...

${ }^{52}$ V. Mitrokhin, op. cit., s. 30.

${ }^{53}$ CPSU CC Politburo Decisions on Afghanistan, 13 IX 1979, http://digitalarchive.wilsoncenter.org/ document/111561 [dostęp: 18 X 2014].
} 
członków rządu o agenturalność wobec CIA ${ }^{54}$. Następnego dnia zamordował swojego rywala politycznego i objął po nim funkcję prezydenta kraju (14 IX 1979-27 XII 1979) ${ }^{5}$. Już od połowy września z prezydentem Aminem zaczął spotykać się amerykański charge d'affaires w Kabulu Bruce Amstutz, który skutecznie go przekonywał, żeby nie przejmował się sojuszem z ZSRS, ponieważ USA utrzymuje stałą obecność w Afganistanie ${ }^{56}$. Zmiana władzy nie uspokoiła jednak sytuacji w kraju, ponieważ nowy prezydent jeszcze bardziej niż poprzednik znienawidzony był przez afgańskie społeczeństwo za szerzenie w kraju terroru. W praktyce wojna w Afganistanie zaczęła się jeszcze przed sowiecką inwazją ${ }^{57}$. Niektóre źródła oceniają, że do momentu interwencji sowieckiej w wyniku bombardowań, eksterminacji całych wiosek, zsyłek do obozów koncentracyjnych i tortur w Afganistanie zginęło nawet ok. 100 tys. ludzi, a 500 tys. udało się na emigrację ${ }^{58}$. Jesienią 1979 r. afgański reżim stracił kontrolę nad prawie całym terytorium kraju i był bliski upadku ${ }^{59}$.

Nowy prezydent nie cieszył się poparciem Moskwy. W odróżnieniu od Tarakiego i Karmala Amin prawdopodobnie nigdy nie został zwerbowany jako agent KGB (Komitiet gosudarstwiennoj biezopasnosti - Komitet Bezpieczeństwa Państwowego) ${ }^{60}$. I sekretarz KPZR Leonid Breżniew (1964-1982) coraz poważniej rozważał wysłanie wojsk sowieckich do Afganistanu, na co nalegał szef KGB Jurij Andropow (1967-1982) ${ }^{61}$. Słaba i niezdecydowana odpowiedź prezydenta Cartera na rewolucję Saur i rewolucję irańską dawała Breżniewowi i jego doradcom nadzieję, że inwazja na Afganistan mogłaby się spotkać z relatywnie ograniczoną reakcją Stanów Zjednoczonych i tym samym społeczności międzynarodowej $^{62}$. Po przejęciu władzy przez Hafizullaha Amina Związek Sowiecki zaczął w szybkim tempie gromadzić jednostki bojowe przy granicy z Afganistanem i wysyłać w głąb kraju oddziały sił specjalnych. Komitet Centralny KPZR we współpracy z dowództwem Armii Czerwonej, opracowując plany inwazji na Afganistan, przygotowywał również scenariusz usunięcia prezydenta Amina ${ }^{63}$. Informacje o wzmożonej aktywności Armii Czerwonej publikowali od początku grudnia 1979 r. sami Amerykanie. 21 grudnia podali, że ZSRS skierował ku granicy z Afganistanem swoje trzy dywizje, a w ostatnich tygodniach do kraju przedostało się przynajmniej 1,5 tys. sowieckich żołnierzy ${ }^{64}$. Amerykańscy analitycy rządowi nadal jednak wątpili, by Sowieci zdecydowali się na okupację kraju, ponosząc za to wysokie polityczne i ekonomiczne koszty ${ }^{65}$. Ponadto poza Zbigniewem Brzezińskim i kilkoma innymi osobami mało kto z amerykańskiej administracji uważał, że ewentualne zaangażowanie ZSRS w Afganistanie mogłoby być pierwszym krokiem do przejęcia hegemonii w Azji

\footnotetext{
${ }^{54}$ R. Piekarowicz, Cień Amanullaha, Warszawa 1984, s. 220.

${ }^{55}$ K. Mroziewicz, Kabul w okresie postu, Kraków 1990, s. 10.

${ }^{56}$ J. Modrzejewska-Leśniewska, Afganistan, s. 324.

${ }^{57}$ R. Sikorski, op. cit., s. 29.

${ }^{58}$ S. Courtois, N. Werth, J. L. Panné, A. Paczkowski, K. Bartošek, J. L. Margolin, Czarna księga komunizmu. Zbrodnie, terror, prześladowania, tł. K. Wakar, Warszawa 1999, s. 668.

${ }^{59}$ R. Sikorski, op. cit.

${ }^{60}$ Ch. A. W. Mitrochin, Archiwum Mitrochina II. KGB i świat, Poznań 2006, s. 427.

${ }^{61}$ Tamże, s. 432, 433.

${ }^{62} \mathrm{~J}$. Bellos, The Soviet military invasion and involvement in Afghanistan, 1979-1988, http://atp.uclan. ac.uk/buddypress/diffusion/?p=1948 [dostęp: 27 IV 2014], za: R. O. Freedman, Moscow and the Middle East: Soviet Policy since the Invasion of Afghanistan, Cambridge 1991, s. 74.

${ }^{63}$ Alexander Lyakhovskiy's Account of the Decision of the CC CPSU Decision to Send Troops to Afghanistan, 1 XI 1979, http://digitalarchive.wilsoncenter.org/document/115531 [dostęp: 20 X 2014].

${ }^{64}$ R. Piekarowicz, op. cit., s. 247.

${ }^{65}$ Milestones: $1977-1980 \ldots$
} 
Południowo-Zachodniej ${ }^{66}$. Większość amerykańskich oficjeli uważała, że Sowieci po prostu bali się upadku państwa w swojej sferze wpływów, dlatego podejmowali bardziej aktywne działania $^{67}$.

Prezydent Amin próbował przekonać stronę amerykańską o swojej lojalności, dlatego akcentował możliwość rozwiązania skomplikowanej sytuacji w kraju bez zaangażowania ZSRS. 12 grudnia „Kabul News Times” opublikował artykuł, że Afganistan pragnie pomocy USA, ale bez warunków, czyli innej, niż otrzymuje od Sowietów ${ }^{6}$. Przedstawiciele amerykańskiego rządu żywili jednak do Amina urazę, pamiętając jego obojętne i obraźliwe zachowanie na pogrzebie ambasadora Dubsa, kiedy nawet nie podpisał księgi kondolencyjnej i nie pojawił się na lotnisku podczas ceremonii pożegnania zwłok ${ }^{69}$. Ponadto, widząc destabilizację Afganistanu, nie chcieli wesprzeć Amina, obawiając się negatywnych konsekwencji takiej współpracy ${ }^{70}$.

\section{Administracja Jimmy’ego Cartera wobec sowieckiej inwazji na Afganistan}

Zdecydowany opór społeczeństwa wobec rządów LDPA w Afganistanie wywołał na Kremlu obawy, że może dojść do jej obalenia i powstania u granic ze Związkiem Sowieckim nowego antykomunistycznego reżimu ${ }^{71}$. Członkowie Komitetu Centralnego KPZR mieli nadzieję, że szybka i zdecydowana interwencja zbrojna zabezpieczy sowieckie interesy w Afganistanie i będzie przykładem realizacji doktryny Breżniewa, zakładającej, że państwo, które raz przyjęło wzorowany na sowieckim ustrój komunistyczny, już nigdy nie przejdzie do obozu kapitalistycznego ${ }^{72}$. Optymizm ten opierał się na daleko odbiegających od rzeczywistości raportach tzw. grupy afgańskiej, w której skład wchodzili: Jurij Andropow, Dmitrij Ustinow, Andriej Gromyko i Boris Ponomariow ${ }^{73}$. Niemniej jednak amerykańscy dyplomaci również przewidywali, że pacyfikacja kraju może zająć kilka dni lub tygodni, podobnie jak w 1956 r. Węgier i w 1968 r. Czechosłowacji ${ }^{74}$. Przekonania tego nie słabiał fakt, że kiedy wojska sowieckie wkraczały do Afganistanu, w dwudziestu pięciu z dwudziestu ośmiu prowincji działał już zbrojny ruch oporu ${ }^{75}$. Wkroczenie wojsk sowieckich znacząco zwiększyło wsparcie dla rebeliantów zarówno ze strony społeczeństwa, jak i władz innych państw, dzięki czemu ich działalność stawała się bardziej spójna i zorganizowana i uniemożliwiła Armii Czerwonej szybką pacyfikację kraju ${ }^{76}$.

W obliczu destabilizacji kraju w nocy z 24 na 25 XII 1979 r. do Afganistanu wkroczyły jednostki zmechanizowane i powietrznodesantowe 40 Ogólnowojskowej Armii Turkiestańskiego Okręgu Wojskowego, które na koniec miesiąca osiągnęły liczbę 8-10 tys. żołnierzy $^{77}$. 27 grudnia Hafizullah Amin został zamordowany przez sowiecki Specnaz

${ }^{66}$ J. Modrzejewska-Leśniewska, Polityka Stanów Zjednoczonych..., s. 349.

${ }^{67}$ S. G. Jones, op. cit., s. 21.

${ }^{68} \mathrm{~K}$. Mroziewicz, op. cit., s. 10.

${ }^{69}$ M. Jabeen, M. S. Mazhar, N. S. Goraya, op. cit., s. 155.

70 J. Modrzejewska-Leśniewska, Afganistan, s. 324.

71 J. Bellos, op. cit., za: R. O. Freedman, op. cit., s. 71-73.

${ }^{72}$ Milestones: 1977-1980...

${ }^{73}$ Ch. A. W. Mitrochin, op. cit., s. 436.

${ }^{74}$ R. Sikorski, op. cit., s. 29.

${ }^{75}$ K. Harvey, op. cit., za: D. C. Isby, War in a Distant Country, New York 1990, s. 19.

76 J. Bellos, op. cit., za: T. Barfield, Afghanistan: A Cultural and Political History, Princeton 2010, s. $236,237$.

77 Intelligence, Afghanistan 1979-1992, http://www.globalsecurity.org/intell/ops/afghanistan.htm [dostęp: 18 X 2014]. 
(Specjalnoje Naznaczenie-Specjalne Przeznaczenie), a jego pałac rozgrabiony przez agentów $\mathrm{KGB}^{78}$. Na miejsce Amina dwa dni wcześniej Sowieci zainstalowali lojalnego wobec Kremla przywódcę Parchamu Babraka Karmala na stanowisku prezydenta (1979-1986) i premiera (1979-1981) Afganistanu. Na potrzeby propagandowe nowe kierownictwo oskarżyło pośmiertnie Amina o to, że był agentem CIA i dlatego po objęciu władzy robił wszystko, aby zniszczyć LDPA, ,zohydzić" hasła rewolucyjne w oczach i uszach Afgańczyków i doprowadzić kraj do katastrofy. Jako dowód przypomniano okres studiów Amina w USA, kiedy pełnił funkcję prezesa Stowarzyszenia Studentów Afgańskich, które miało być infiltrowane i finansowane przez CIA ${ }^{79}$.

Już w grudniu 1979 r. Amerykanie we współpracy z krajami arabskimi uruchomili własną antysowiecką i antykomunistyczną machinę propagandową. Audycje „Głosu Ameryki” i innych radiostacji nadawane były w językach dari i pasztu po kilkanaście godzin na dobę. Dzięki japońskim odbiornikom tranzystorowym mogły być słuchane nawet w zapadłych wsiach umiejscowionych $\mathrm{w}$ górskich dolinach kraju. Szkodziły one afgańskiemu reżimowi komunistycznemu znacznie bardziej niż dziesiątki grup kontrrewolucyjnych, a samemu Babrakowi Karmalowi wróżyły śmierć z rąk rodaków za kolaborację z obcym najeźdźcą ${ }^{80}$.

Z kolei sowiecka propaganda jako oficjalny powód interwencji w Afganistanie wskazała konieczność zapewnienie bezpieczeństwa Związkowi Sowieckiemu. Z wypowiedzi przedstawicieli władz ZSRS i artykułów w sowieckiej prasie wynika, że Afganistan był zagrożony utratą niepodległości i przekształceniem w przyczółek militarny Stanów Zjednoczonych, z którego miano dokonać agresji na ZSRS ${ }^{81}$. Podstawą tej teorii był fakt, że wiosną $1979 \mathrm{r}$. CIA rozważało możliwość umieszczenia w Afganistanie aparatury śledzącej testy rakietowe ZSRS prowadzone w republikach środkowoazjatyckich ${ }^{82}$. W lutym 1980 r. ambasador ZSRS w Kabulu Fikrijat Tabiejew (1979-1986) poinformował o wykryciu spisku w najbliższym otoczeniu prezydenta Amina. Spisek ten rzekomo miał dotyczyć wsparcia militarnego ze strony USA, Pakistanu i ChRL dla antyrewolucyjnych sił w Afganistanie i doprowadzić kraj do utraty niepodległości, suwerenności i integralności terytorialnej, nawet kosztem wojny w regionie ${ }^{83}$. Z kolei we wrześniu 1980 r. Konstantin Czernienko przedstawił wkroczenie wojsk sowieckich do Afganistanu jako konieczność obrony zdobyczy rewolucyjnych afgańskiego narodu przed agresją zorganizowanych i uzbrojonych przez USA i Chiny „band” antyrewolucyjnych $^{84}$. Niezależnie od manipulacji informacjami i braku dowodów na wspieranie z zewnątrz afgańskich sił antykomunistycznych Sowieci rzeczywiście się obawiali, że zdestabilizowany Afganistan mógł zagrozić południowej granicy ZSRS i zmusić ich do utrzymywania $\mathrm{w}$ rejonie znacznych sił $^{85}$. Spekulowali, że Stany Zjednoczone mogłyby wykorzystać tę sytuację, przejmując wpływy w Afganistanie i w przyszłości traktować go jako bazę operacyjną przeciwko ZSRS w jego „miękkim podbrzuszu”, czyli w Azji Środkowej ${ }^{86}$. Na potrzeby uzasadnienia inwazji przed społecznością międzynarodową władze w Moskwie powołały się na fakt wielokrotnych próśb, szczególnie prezydenta Mohammeda Tarakiego, o sojuszni-

78 J. Smaga, Narodziny i upadek imperium. ZSRR 1917-1991, Kraków 1992, s. 378.

${ }^{79}$ R. Piekarowicz, op. cit., s. 214, 215.

${ }^{80}$ Ibidem, s. 286.

${ }^{81}$ S. E. Mendelson, Changing Course. Ideas, Politics, and the Soviet Withdrawal from Afghanistan, Princeton 1998, s. 60, 61.

${ }^{82}$ J. Modrzejewska-Leśniewska, s. 334.

${ }^{83}$ V. Mitrokhin, op. cit., s. 108.

${ }^{84}$ S. E. Mendelson, op. cit., s. 76.

${ }^{85}$ V. Mitrokhin, op. cit., s. 109, 110.

${ }^{86}$ S. G. Jones, op. cit., s. 18. 
czą interwencję zbrojną. W związku z tym ogłosiły, że wejście wojsk sowieckich było zgodne artykułem 51 Karty Narodów Zjednoczonych o indywidualnej i kolektywnej samoobronie ${ }^{87}$. W rzeczywistości jednak była to bezprawna agresja zbrojna na suwerenne państwo. W związku z tym Stany Zjednoczone jako przywódca „wolnego świata” musiały zareagować, aby zatrzymać rozprzestrzenianie się komunistycznych wpływów na kolejne terytoria ${ }^{88}$.

Sowiecka interwencja w Afganistanie była wyznacznikiem końca okresu détente w globalnej zimnej wojnie ${ }^{89}$. Ponadto była pierwszym po drugiej wojnie światowej otwartym użyciem żołnierzy sowieckich poza żelazną kurtyną dla okupowania państwa niezaangażowanego bezpośrednio w międzyblokową rywalizację. $Z$ wielu względów akt ten mógł być odczytany jako próba potwierdzenia przez Związek Sowiecki, że jest dominującą potęgą światową ${ }^{90}$. W wywiadzie telewizyjnym z 31 XII 1979 r. prezydent Carter powiedział, że sowiecki atak na Afganistan to najpoważniejszy kryzys po drugiej wojnie światowej. Skrytykował władze w Moskwie za rażące łamanie zasad współpracy międzynarodowej i powiedział, ze całkowicie zmieniło to jego zdanie o sowieckim przywództwie ${ }^{91}$. Prezydent Carter jednoznacznie potępił interwencję i przystąpił do opracowania planu odpowiedzi na działania Sowietów ${ }^{92}$.

Tym razem ostrzeżenia Zbigniewa Brzezińskiego miały dla prezydenta Cartera znacznie bardziej realny wymiar. Zrozumiał on, że jeśli Związek Sowiecki zdominuje Afganistan, to następnym jego krokiem może być próba rozbioru Pakistanu przez promowanie powstania samodzielnego Beludżystanu, co dałoby ZSRS dostęp do Oceanu Indyjskiego i umożliwiło penetrację Iranu ${ }^{93}$. Biuro Polityczne KPZR nie wykluczało takiej możliwości, jednak nie była to też zasadnicza strategia ${ }^{94}$. Gdy Mohammed Taraki i później również Babrak Karmal forsowali potrzebę stworzenia wielkiego Afganistanu z dostępem do Oceanu Indyjskiego, strona sowiecka odpowiadała, że sprawa ta musi poczekać do czasu, aż zostanie umocniony komunizm w Afganistanie ${ }^{95}$. Prezydent Carter w przemówieniu z 4 I 1980 r. przedstawił ryzyko realizacji takiego scenariusza i zapowiedział zdecydowaną reakcję na działania Sowietów. Zbigniew Brzeziński, mając w tamtym czasie największy wpływ na decyzje prezydenta Cartera w kwestii polityki zagranicznej, zarysował trzy główne kierunki działania. Dotyczyły one stworzenia regionalnego systemu bezpieczeństwa, w którym wyraźne byłyby jego związki z interesem USA, nałożenia sankcji na Związek Sowiecki oraz modyfikacji doktryny bezpieczeństwa z uwzględnieniem wzrostu wydatków na zbrojenia ${ }^{96}$. Doradcy prezydenta, w tym Zbigniew Brzeziński, zdawali sobie sprawę, że bezpośrednia konfrontacja militarna ze Związkiem Sowieckim nie była możliwa nie tylko ze względów strategicznych, ale również z powodu niechęci wobec siłowych rozwiązań społeczeństwa amerykańskiego mającego świeżo w pamięci klęskę w „Wietnamie. Najbardziej wyraziście eksponował to wiceprezydent Walter Mondale (1977-1981), wskazując, że kontrofensywa militarna z pew-

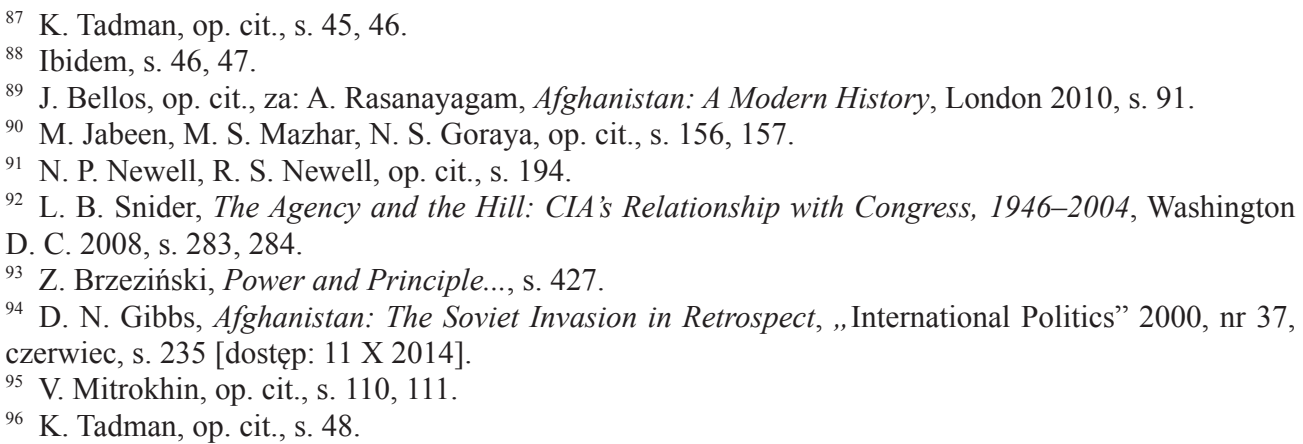


nością uniemożliwiłoby Jimmy’emu Carterowi reelekcję ${ }^{97}$. Zdominowana przez Zbigniewa Brzezińskiego Rada Bezpieczeństwa Narodowego przygotowała wraz Sekretariatem Stanu listę działań odwetowych, które mogłyby być zastosowane w reakcji na sowiecką inwazję na Afganistan $^{98}$.

$\mathrm{Z}$ racji położenia geograficznego, wielu powiązań $\mathrm{z}$ poszczególnymi podmiotami w Afganistanie oraz sojuszniczej bliskości z USA kluczowym partnerem w realizacji amerykańskiej strategii wobec Afganistanu miał być Pakistan. Zgodnie z koncepcją Zbigniewa Brzezińskiego dostawy broni, szkolenie i finansowanie mudżahedinów miało organizować CIA za pośrednictwem pakistańskiego wywiadu (Inter-Services Intelligence Directorate/ Departament Służb Wywiadu - ISI), co w razie konieczności pozwoliłoby Amerykanom przekonująco zaprzeczyć, że są zaangażowani w konflikt ${ }^{99}$. 9 I 1980 r. CIA przedstawiło senackiej komisji ds. wywiadu plan udzielenia mudżahedinom wsparcia w wysokości $30 \mathrm{mln}$ dol., czemu Kongres się nie sprzeciwił ${ }^{100}$. Na tej podstawie już w styczniu do Afganistanu trafiła dostawa starych, powszechnie używanych w kraju brytyjskich karabinów LeeEnfield $303^{101}$, co miało zagwarantować, że nie zostaną one zidentyfikowane jako zagraniczna pomoc ${ }^{102}$. Mimo to już w lutym 1980 r. do mediów przedostawały się informacje, że CIA przerzuca przez Pakistan broń dla afgańskich mudżahedinów ${ }^{103}$. Kiedy w kwietniu 1980 r. Cyrus Vance ustąpił z funkcji sekretarza stanu, jasne było, że zwyciężyła opcja Zbigniewa Brzezińskiego nadania CIA wiodącej roli w przeciwdziałaniu ZSRS w Afganistanie za pośrednictwem ISI ${ }^{104}$. Opracowywano wtedy plan wsparcia mudżahedinów na większą skalę. Mechanizm dostaw broni miał polegać na tym, że CIA skupowało w państwach regionu broń produkcji sowieckiej i rozprowadzało ją za pośrednictwem ISI, aby nie było możliwości dotarcia do rzeczywistych sponsorów ${ }^{105}$.

$\mathrm{Na}$ drodze do realizacji planów Zbigniewa Brzezińskiego stały władze Pakistanu. Już kilka dni po wejściu wojsk sowieckich do Afganistanu prezydent Jimmy Carter w rozmowie telefonicznej z prezydentem Pakistanu Mohammedem Zia ul-Haqiem (1978-1988) zaoferował $400 \mathrm{mln}$ dol. gospodarczej i wojskowej pomocy Pakistanowi w zamian za współpracę we wspieraniu afgańskiego powstania ${ }^{106}$. Początkowo prezydent Zia ul-Haq odrzucił tę ofertę, uznając ją za minimalną. Poza tym bardziej zależało mu na amerykańskich gwarancjach obrony pakistańskiej granicy, czego strona amerykańska nie mogła spełnić ${ }^{107}$. Problem polegał na tym, że chodziło nie tylko o obronę przed zagrożeniem ze strony ZSRS, ale także o potencjalne roszczenia terytorialne Afgańczyków wobec Pasztunistanu i obronę przed Indiami, z którymi Pakistan znajdował się w konflikcie o Kaszmir ${ }^{108}$. Ponieważ administracja Jimmy’ego Cartera nie sprostała oczekiwaniom pakistańskiego prezydenta, ten godził się jedynie na ograniczone działania ze swojego terytorium. Dopiero prezydent Ronald Reagan (1981-1989) przekonał Kongres w 1981 r. do zatwierdzenia 3,2 mld dol. na pięcioletni pro-

\footnotetext{
${ }^{97}$ Ibidem, s. 52.

${ }_{98}$ Z. Brzeziński, Power and Principle..., s. 430.

99 J. Cooley, Unholy Wars: Afghanistan, America and International Terrosism, Virginia 1999, s. 14.

100 J. Modrzejewska-Leśniewska, Afganistan, s. 350.

${ }^{101}$ S. G. Jones, op. cit., s. 20.

${ }_{102}$ J. Modrzejewska-Leśniewska, Afganistan, s. 350.

${ }^{103}$ N. P. Newell, R. S. Newell, s. 188.

${ }^{104}$ K. Tadman, op. cit., s. 39, 40.

${ }^{105}$ A. Z. Halili, U.S.-Pakistan Relationship: Soviet Invasion of Afghanistan, Burlington 2005, s. 155.

${ }^{106}$ K. Harvey, op. cit., za: Digital National Security Archive.

${ }^{107}$ M. Jabeen, M. S. Mazhar, N. S. Goraya, op. cit., s. 158.

${ }^{108}$ N. P. Newell, R. S. Newell, op. cit., s. 197.
} 
gram pomocowy dla Pakistanu. Pozwoliło to na daleko idącą realizację planów poprzedniej administracji ${ }^{109}$ uczynienia $\mathrm{z}$ tego kraju pośrednika w przekazywaniu militarnej i finansowej pomocy dla walczących w Afganistanie mudżahedinów ${ }^{110}$. W pakistańskim Peszawarze znajdowały się siedziby siedmiu ich partii, które dzięki poparciu gospodarzy od początku wojny otrzymywały wsparcie CIA ${ }^{111}$.

Prezydent Carter liczył również na zaangażowanie się w konflikt innych państw muzułmańskich, które jednogłośnie skrytykowały inwazję na Afganistan ${ }^{112}$. O ile faktycznie mógł liczyć na wsparcie polityczne i finansowe ze strony konserwatywnych krajów regionu, o tyle jedynie Egipt zaoferował sojuszniczą pomoc w wymiarze militarnym. Przywódcy innych zaprzyjaźnionych państw, jak np. Arabia Saudyjska i Jordania, zachowali większą wstrzemięźliwość, ponieważ obawiali się, że bliska współpraca militarna z USA, od dekad popierających Izrael, mogłaby zarówno podkopać ich poparcie w społeczeństwie, jak i osłabić pozycję w regionie rządzonych przez nich państw ${ }^{113}$. Niemniej jednak to właśnie Arabia Saudyjska i inne konserwatywne monarchie regionu Zatoki Perskiej stały się głównymi sponsorami działań afgańskich mudżahedinów ${ }^{114}$. Saudyjska rodzina „królewska przeznaczyła na tę pomoc 4 mld dol., a do tego należy jeszcze doliczyć nieoficjalną pomoc z fundacji, organizacji charytatywnych, zbiórek w meczetach i dotacji biznesmenów, których nie sposób oszacować ${ }^{115}$.

Poważnie traktując zagrożenie ze strony ZSRS, prezydent Jimmy Carter w orędziu o stanie państwa z 23 I 1980 r. przedstawił nową doktrynę, w której ogłosił, że jakakolwiek próba przejęcia kontroli nad regionem Zatoki Perskiej będzie uznana za atak na żywotne interesy USA i odparta wszelkimi niezbędnymi środkami, włącznie z użyciem sił zbrojnych ${ }^{116}$. Niewątpliwie wpływ na opracowanie doktryny miało nie tylko zagrożenie ze strony ZSRS, ale również kryzys naftowy z lat 1973-1974 wywołany wojną Jom Kipur i kryzys naftowy z lat 1979-1980 spowodowany rewolucją irańską ${ }^{117}$. Mimo braku nakreślenia precyzyjnych granic dla „doktryny Cartera”, nie ulegało wątpliwości, że Afganistan znajduje się poza Zatoką Perską. Była to więc wyraźna informacja, że Stany Zjednoczone nie podejmą bezpośrednich działań zbrojnych, które miałyby zmusić ZSRS do wycofania się z tego kraju ${ }^{118}$. Konsekwencją ogłoszenia doktryny Cartera było jednak wydanie 15 I 1981 r. prezydenckiej dyrektywy NSC-63, która przesądzała o zwiększeniu zaangażowania amerykańskich sił w regionie ${ }^{119}$ i wzmocnieniu tamtejszych układów bezpieczeństwa ${ }^{120}$.

\footnotetext{
109 J. Viret, The Reagan Doctrine: No de Facto Effect on America's Intervention in Afghanistan, „Menlo Roundtable" 2013, Issue 14, Spring, s. 18, 19, http://roundtable.menloschool.org/issue14/3_Viret_MS Roundtable14_Spring_2013.pdf.

${ }_{110}$ M. Jabeen, M. S. Mazhar, N. S. Goraya, op. cit., s. 158, za: D. Kux, American Changing Outlook on Afghanistan, „Pakistan Journal of American Studies” 1996, Spring and Fall, s. 18.

${ }_{111}$ A. Rashid, op. cit., s. 45.

112 Z. Brzeziński, Cztery lata w Białym Domu, Warszawa 1990, s. 462.

${ }^{113}$ N. P. Newell, R. S. Newell, op. cit., s. 195-198.

${ }_{114}$ G. Kepel, Święta wojna. Ekspansja i upadek fundamentalizmu muzutmańskiego, tł. K. Pachniak, Warszawa 2003, s. 139.

${ }^{115}$ Ł. Jureńczyk, op. cit., s. 122.

116 Milestones: 1977-1980...

117 R. L. McCan, An Outline Of The American Economy, Washington 1992, s. 193.

118 N. P. Newell, R. S. Newell, op. cit., s. 194, 195.

119 K. Tadman, op. cit., s. 53, za: H. Bradsher, Afghanistan and the Soviet Union, Durham 1995, s. 58.

${ }^{120}$ L. Colucci, The National Security Doctrines of the American Presidency. How They Shape Our Present and Future, t. II, Santa Barbara 2012, s. 383.
} 
Równolegle Stany Zjednoczone rozpoczęły nakładanie na Związek Sowiecki sankcji o charakterze politycznym i gospodarczym. Administracja Cartera jeszcze przed inwazją rozważała możliwość ich wprowadzenia jako instrumentu przeciwdziałania agresji, lecz szybkie działania Sowietów spowodowały, że stały się one bezprzedmiotowe i w perspektywie sytuacja wymagała zupełnie nowego instrumentarium nacisku na ZSRS ${ }^{121}$. Prezydent Carter podjął decyzję o nałożeniu embarga na eksport zboża do Związku Sowieckiego oraz zaprzestaniu transferu nowoczesnych technologii. W zakresie współpracy naukowo-technologicznej zawiesił również rozmowy nad przedłużeniem umowy z 1973 r. o obopólnym dostępie naukowców do instytutów technologicznych w USA i ZSRS ${ }^{122}$. Ograniczył także sowieckim kutrom możliwość połowów na wodach amerykańskich ${ }^{123}$. Wstrzymanie transferu technologii negatywnie odbiło się na funkcjonowaniu sowieckiej gospodarki. Koszty embarga na zboże uderzyły jednak głównie w amerykańskich farmerów i związanych z nimi przedsiębiorców rolnych, którzy ponieśli dotkliwe straty w wyniku utraty sowieckiego rynku zbytu mimo wprowadzenia przez amerykański rząd różnego rodzaju rekompensat. Z kolei Związek Sowiecki bez większych problemów znalazł alternatywnych dostawców surowca ${ }^{124}$. Argentyna całkowicie odrzuciła możliwość udziału w embargu, podpisując z ZSRS w kwietniu 1980 r. pięcioletni kontrakt na zwiększone dostawy zboża ${ }^{125}$. Również inni kluczowi jego eksporterzy, tacy jak Kanada, Australia i Wspólnota Europejska, mimo przyrzeczenia utrzymania eksportu do ZSRS na niezmiennym poziomie, już w połowie $1980 \mathrm{r}$. w praktyce go podwoili $^{126}$.

W ramach reperkusji politycznych amerykański Senat zawiesił ratyfikację podpisanego 18 VI 1979 r. porozumienia rozbrojeniowego SALT II (Strategic Arms Limitation Treaty Traktat o redukcji broni strategicznej). Był to wyraźny sygnał zwrotu w stosunkach amerykańsko-sowieckich, potwierdzający, że nic nie pozostało po okresie détente. Prezydent Carter uznał zawieszenie rozmów rozbrojeniowych za najbardziej rozczarowującą konsekwencję sowieckich działań w Afganistanie ${ }^{127}$. Równocześnie prezydent Carter zaczął naciskać na Kongres w kwestii zwiększenia wydatków na zbrojenia konwencjonalne, szczególnie w zakresie zdolności szybkiego rozmieszczenia sił. O ile w projekcie budżetu na rok 1979 Carter zaproponował wydatki na zbrojenia na poziomie 125,7 mld dol., o tyle na rok 1980 już w wysokości 157,7 mld dol. ${ }^{128}$ Stricte politycznym aspektem wyraźnego ochłodzenia stosunków było tymczasowe wycofanie z Moskwy ambasadora Thomasa Watsona (1979-1981) oraz zawieszenie prac nad otworzeniem w Związku Sowieckim kolejnych konsulatów, co miało jednak negatywne reperkusje głównie dla USA. Decyzją o istotnym znaczeniu propagandowym było z kolei symboliczne odwołanie udziału reprezentacji Stanów Zjednoczonych w olimpiadzie w Moskwie w 1980 r. ${ }^{129}$ Nie udał się jednak międzynarodowy bojkot olimpiady, ponieważ przyłączyło się do niego tylko część państw, m.in. Japonia, ChRL, RFN i kilkadziesiąt

\footnotetext{
${ }^{121}$ J. Modrzejewska-Leśniewska, Polityka Stanów Zjednoczonych..., s. 352-354.

122 Ibidem, za: H. Bradsher, op. cit., s. 194, 195.

${ }_{123}$ M. Jabeen, M. S. Mazhar, N. S. Goraya, op. cit., s. 157.

${ }^{124}$ N. P. Newell, R. S. Newell, op. cit., s. 193.

${ }^{125}$ D. W. Drezner, The Sanctions Paradox. Economic Statecraft and International Relations, Cambridge 1999, s. 74, 75.

${ }^{126}$ R. L. Paarlberg, Lessons of the Grain Embargo, „Foreign Affairs” 1980, Fall, http://www.foreign affairs.com/articles/34274/robert-l-paarlberg/lessons-of-the-grain-embargo [dostęp: 15 XI 2014].

${ }^{127}$ K. Tadman, op. cit., za: J. Carter, Keeping Faith: Memoirs of a President, Fayateville 1995, s. 473.

${ }^{128}$ D. Milczarek, Polityka militarna, w: Carter i jego administracja, red. L. Pastusiak, Warszawa 1980, s. 208-209.

${ }^{129}$ L. S. Kaplan, NATO Divided, NATO United. The Evolution of an Alliance, New York 2012, s. 88, 89.
} 
niezbyt liczących się reprezentacji z różnych kontynentów. Większość europejskich potęg sportowych wzięła udział w zawodach, jedynie z tą różnicą, że zamiast pod flagą narodową, to pod flagą olimpijską.

Amerykanie podnieśli problem sowieckiej inwazji na Afganistan także na forum Organizacji Narodów Zjednoczonych. Zgodnie z przewidywaniami w Radzie Bezpieczeństwa nie udało się uchwalić rezolucji potępiającej agresję, ponieważ z oczywistych względów została ona zawetowana przez Związek Sowiecki mający stałe miejsce w Radzie. 14 I 1980 r. udało się jednak przeforsować podobną rezolucję w Zgromadzeniu Ogólnym. Państwa członkowskie przewagą 104 do 18 głosów potępiły sowiecką interwencję zbrojną w Afganistanie i wezwały do natychmiastowego i bezwarunkowego wycofania z kraju obcych wojsk.

\section{Podsumowanie}

W pierwszej połowie kadencji prezydent Jimmy Carter nie potrafił wypracować skutecznej polityki w odpowiedzi na coraz bardziej zdecydowane działania Związku Sowieckiego w Afganistanie. Było to między innymi wynikiem sprzecznych stanowisk dwóch głównych doradców prezydenta w kwestii realności zagrożenia sowieckiego. To klasyczny problem prezydenckiego procesu decyzyjnego w USA, szczególnie jeśli jedna z rekomendacji jest $\mathrm{z}$ dyplomatycznego, a druga $\mathrm{z}$ siłowego punktu widzenia ${ }^{130}$. O ile doradca ds. bezpieczeństwa Zbigniew Brzeziński naciskał na prezydenta, aby ten przyjął ostry kurs wobec ZSRS i w zarodku zneutralizował zagrożenie dla amerykańskich interesów w Azji Środkowej i Południowo-Zachodniej, o tyle sekretarz stanu Cyrus Vance oponował przeciwko zakłócaniu amerykańsko-sowieckich relacji bez posiadania twardych dowodów na mieszanie się Sowietów w sprawy afgańskie ${ }^{131}$. Przywództwo to jednak sedno prezydenckiej siły, tak więc prezydent musi mieć wyczucie czasu i tempa oraz powinien wiedzieć, kiedy i jak blefować, pertraktować, iść na kompromis i użyć twardszych środków ${ }^{132}$. W tym okresie prezydent Carter był bardziej przychylny umiarkowanemu stanowisku sekretarza stanu Cyrusa, ponieważ zależało mu na utrzymaniu pozytywnej atmosfery détente $e^{133}$. Niemniej jednak za sprawą nacisków Zbigniewa Brzezińskiego już pół roku przed sowiecką inwazją w Afganistanie działali agenci CIA i USA zaczęło w ograniczonym stopniu dostarczać pozamilitarne wsparcie afgańskim rebeliantom ${ }^{134}$.

Stany Zjednoczone, które przez lata ignorowały zagrożenie komunistyczne w Afganistanie, wraz z sowiecką interwencją nagle przebudziły się z tej obojętności i podjęły zdecydowane kroki wobec ZSRS ${ }^{135}$. W okresie okupacji Afganistanu przez Armię Czerwoną zaangażowały się $\mathrm{w}$ zastępczą wojnę z zimnowojennym wrogiem, wspierając islamskich bojowników. Jak podsumował to John K. Cooley, „Ameryka kocha romansować z islamem" "136. Przedstawiciele amerykańskiej administracji uznali, że pomoc udzielana afgańskim mudżahedinom będzie genialnym posunięciem strategicznym. Mogli przez to pozyskać zupełnie obcych ludzi w odległym kraju do walki za sprawę amerykańską.

\footnotetext{
130 P. H. Aranson, American Government. Strategy and choice, Cambridge 1981, s. 424.

131 M. Jabeen, M. S. Mazhar, N. S. Goraya, op. cit., s. 157, za: D. Cordovez, S. S. Harrison, Out of Afghanistan: The Inside Story of Soviet Withdrawal, London 1995, s. 33.

132 R. M. Pious, American Politics and Government, New York 1986, s. 356.

133 J. Spanier, op. cit., s. 18.

134 K. Tadman, op. cit., s. 61.

135 M. Jabeen, M. S. Mazhar, N. S. Goraya, op. cit.., s. 157.

136 J. Cooley, op. cit., s. xiv.
} 
Przez to nie musieli wysyłać własnych sił zbrojnych i tłumaczyć przed społeczeństwem ofiar wśród swoich żołnierzy.

Politykę prezydenta Jimmy'ego Cartera polegającą na sponsorowaniu afgańskiej rebelii kontynuował republikański prezydent Ronald Reagan (1981-1989). Skala tego wsparcia była jednak zupełnie inna podczas sprawowania władzy przez obie administracje. Kiedy Carter kończył urzędowanie w styczniu 1981 r., Stany Zjednoczone wydawały rocznie na pomoc dla mudżahedinów mniej więcej $60 \mathrm{mln}$ dol. ${ }^{137}$ Natomiast do 1985 r. przeznaczyły na tę pomoc już 4 mld dol., z czego zdecydowaną większość podczas prezydentury Ronalda Reagana ${ }^{138}$. Większe dostawy broni dla mudżahedinów zaczęły dopiero po kilku latach oporu ${ }^{139}$. Sama koncepcja pomocy, która okazała się niezbędna do pokonania Sowietów, opracowana została jednak za prezydentury Jimmy’ego Cartera, a jej głównym architektem był Zbigniew Brzeziński. Wraz z przedłużającą się sowiecką obecnością militarną w Afganistanie Stany Zjednoczone coraz bardziej były zmotywowane do „wykrwawienia” ZSRS, stąd sukcesywnie rosła skala wsparcia dla rebeliantów ${ }^{140}$.

Zapoczątkowana przez prezydenta Cartera i kontynuowana przez prezydenta Reagana polityka wsparcia afgańskich mudżahedinów za pośrednictwem Pakistanu doprowadziła do pokonania ZSRS. Mimo corocznych wydatków Związku Sowieckiego w Afganistanie, szacowanych przez CIA na 7 mld dol. W latach 1980-1986, Rosjanie ponieśli klęskę ${ }^{141}$. Do lutego 1989 r. wycofali się z kraju. Ich straty wyniosły ok. 14,5 tys. zabitych i blisko 470 tys. rannych i chorych. Pozostawili za sobą zdewastowany kraj i 1,5 mln afgańskich ofiar, z czego ok. 80 proc. stanowili cywile ${ }^{142}$. Konflikt doprowadził również do wypchnięcia z kraju prawie 6 mln ludzi, z czego ponad 3 mln trafiło do Pakistanu. Amerykańskie wsparcie przechodziło przez pakistańskie ISI, które z małej, nieznaczącej organizacji przekształciło się w potężną siłę $^{143}$. Wzmocnione przez Amerykanów ISI odegrało później kluczową rolę w zagospodarowaniu młodych uchodźców o radykalnych poglądach, umożliwiając powstanie ruchu talibów, który przejął władzę w Afganistanie i stworzył jeden z najbardziej represyjnych reżimów na świecie $^{144}$. Wieloletni, krwawy konflikt pozostawił za sobą nie tylko zniszczony kraj, a także dobrze wyszkolonych, zaprawionych w boju islamskich radykałów, w których umysłach szybko pojawila się wrogość wobec wcześniejszych sojuszników w walce z komunistyczną inwazją $^{145}$. W ten sposób powstała Al-Kaida, która znalazła dla siebie znakomite warunku w utrzymującym się z produkcji narkotyków państwie talibów ${ }^{146}$. Jej błyskawiczny rozwój możliwy był również dzięki temu, że amerykańskie dostawy broni i pomoc szkoleniowa $\mathrm{z}$ okresu sowieckiej okupacji nie zawsze trafiały do odpowiednich adresatów ${ }^{147}$. Amerykanie oceniają, że w latach 1985-1992 12,5 tys. obcokrajowców zostało przeszkolonych w zakresie

\footnotetext{
137 J. Modrzejewska-Leśniewska, Afganistan, s. 350.

138 J. Bellos, op. cit., za: M. Galeotti, Afghanistan: The Soviet Union's Last War, Abingdon 2001, s. 18.

139 R. Sikorski, op. cit., s. 349.

140 K. Tadman, op. cit., s. 60.

141 Directorate of Intelligence, The Costs of Soviet Involvement in Afghanistan. An Intelligence Assessment, styczeń 1987, http://www.foia.cia.gov/docs/DOC_0000499320/DOC_0000499320.pdf [dostęp: 6 V 2014].

142 J. Modrzejewska-Leśniewska, Afganistan, s. 368.

143 S. G. Jones, op. cit., s. 30.

144 Ł. Jureńczyk, op. cit., s. 45-57, 89-101.

145 K. Harvey, op. cit.

146 Ł. Jureńczyk, op. cit., s. 104-107.

147 R. Sikorski, op. cit., s. 349.
} 
konstruowania bomb, sabotażu i partyzantki miejskiej w utworzonych z pomocą CIA afgańskich obozach $^{148}$.

Administracja Jimmy'ego Cartera stworzyła podstawy spójnej strategii wobec zagrożenia ze strony Związku Sowieckiego dla Zatoki Perskiej, która uznawana była przez kolejne amerykańskie administracje ${ }^{149}$. Mimo że tworzono ją z myślą o powstrzymaniu ekspansjonistycznej polityki ZSRS, to dotyczyła wszystkich państw, które potencjalnie zdecydowałyby się na opanowanie tego bogatego w surowce energetyczne regionu. W praktyce kolejni amerykańscy prezydenci realizowali ją w celu ochrony interesów Stanów Zjednoczonych w Zatoce Perskiej. Najbardziej ,spektakularnym przykładem była zdecydowana reakcja prezydenta George’a Busha (1989-1993) w 1991 r. na iracką próbę aneksji Kuwejtu. Utworzył on wielką koalicję międzynarodową, która siłowo odpowiedziała agresorowi ${ }^{150}$.

Inicjowanym przez administrację Jimmy'ego Cartera rozwiązaniom strategiczno-militarnym towarzyszyły sankcje gospodarcze i polityczne nakładane przez Stany Zjednoczone na Związek Sowiecki. Miały one uczynić sowiecką obecność militarną w Afganistanie tak bolesną i krótkotrwałą, jak to tylko możliwe ${ }^{151}$. Ekonomiczne represje powinny wymóc na ZSRS zmianę postępowania lub wyznaczyć za nie cenę ${ }^{152}$. Skuteczność tego rodzaju sankcji nałożonych przez administrację prezydenta Cartera jest jednak dyskusyjna. O ile ograniczenia w transferze technologii pogłębiły kryzys gospodarczy w Związku Sowieckim, o tyle embargo na eksport zboża nie przyniosło oczekiwanych rezultatów. Ponadto bez wątpienia sankcje te pogłębiły destabilizację na linii Wschód-Zachód ${ }^{153}$. Nie udał się również symboliczny bojkot Olimpiady w Moskwie, a rezolucja Zgromadzenia Ogólnego ONZ potępiająca sowiecką interwencję w praktyce na niewiele się zdała. Z kolei zamrożenie układów SALT II były tak samo porażką ZSRS, jak i USA.

Działania na forum międzynarodowym podjęte przez administrację Jimmy’ego Cartera z pewnością zirytowały stronę sowiecką i w pewnym stopniu wyalienowały ją ze społeczności międzynarodowej, jednak nie wpłynęły znacząco na zmianę sytuacji stworzonej przez interwencję Moskwy. Były one dość powierzchowne, ponieważ nie miały wyraźnego umocowania $\mathrm{w}$ realiach powstałych po inwazji ${ }^{154}$. Nieumiejętność podejmowania szybkich i zdecydowanych decyzji, między innymi w kwestii Afganistanu i Iranu, ale także wielu innych wydarzeń międzynarodowych i wewnętrznych spowodowały, że prezydent Carter nie został wybrany na drugą kadencję ${ }^{155}$.

\footnotetext{
148 J. Burke, Frankenstein the CIA crated, „The Guardian” 17 I 1999, http://www.theguardian.com/ world/1999/jan/17/yemen.islam [dostęp: 10 X 2014].

${ }^{149}$ K. Tadman, op. cit, s. 31-33.

150 J. Bulloch, H. Morris, Wojna Saddama. Początki konfliktu kuwejckiego i reakcja międzynarodowa, Poznań 1991, s. 104.

151 Milestones: 1977-1980...

152 J. Spanier, op. cit., s. 13.

153 J. Kaczurba, Problemy zagranicznej polityki gospodarczej, w: Carter i jego administracja, s. 150.

${ }_{154}$ Ibidem, s. 194.

155 J. M. Shafritz, American Government and Politics, New York 1993, s. 72.
} 


\section{The Reaction of the Jimmy Carter Administration to the Communist Takeover and Soviet Army Intervention in Afghanistan}

The article examines the actions taken by the administration of President Jimmy Carter in response to the Saur Revolution of April 1978 and the initial stage of the Soviet invasion of Afghanistan. It presents the contradictory positions of the presidential administration officials who had the greatest influence on the formulation of foreign and security policy of the United States during this period. First of all, highlighted the differing positions of Secretary of State Cyrus Vance, who advocated a moderate reaction to the events and focus on diplomatic solutions and National Security Advisor Zbigniew Brzezinski, who called for stricter policy towards the Soviet Union and the communist Afghan authorities. Presented circumstances which motivated President Jimmy Carter to rely on the suggestions of particular advisers in the decision-making process. The article presents political, economic and military decisions made by the American government against the Soviet Union and Afghanistan and examines their effectiveness and consequences.

Translated by Łukasz Jureńczyk 